\title{
Can biological products control Neonectria ditissima picking wound and leaf scar infections in apples?
}

\author{
M. Walter ${ }^{1}$, R.E. Campbell ${ }^{1}$, N.T. Amponsah², L. Turner ${ }^{1}$, D. Rainham ${ }^{3}$, U. Kerer ${ }^{3}$, and \\ R.C. Butler ${ }^{4}$ \\ ${ }^{1}$ The New Zealand Institute for Plant \& Food Research Ltd (PFR), 55 Old Mill Road, RD3, \\ Motueka, New Zealand \\ ${ }^{2}$ PFR, Havelock North Research Centre, Corner Crosses and St Georges Road, Havelock North, \\ New Zealand \\ ${ }^{3}$ AgFirst Ltd, 171 High Street, Motueka, New Zealand \\ ${ }^{4}$ PFR, Canterbury Agriculture \& Science Centre, Gerald Street, Lincoln, New Zealand \\ Corresponding author: monika.walter@plantandfood.co.nz
}

\begin{abstract}
Neonectria ditissima is the causal agent of European canker in apple, and conidia infect wounds in apple trees. Several commercially available chemical fungicides and biological products (BPs) were tested for wound protection activity in three field experiments (2014-17). Freshly made wounds (rasp, picking, leaf and/or bud scar) were sprayed with the products at label rates. Wounds were challenge-inoculated with $N$. ditissima conidia after 24 hours and monitored monthly for lesion development. Only captan and copper oxide consistently protected wounds from infection and disease development in each experiment. The BPs tested in this study did not provide adequate wound protection when challenge-inoculated with $N$. ditissima at high concentration (>1000 spores/wound) so are not recommended for wound protection during harvest and leaf fall when disease pressure is high.
\end{abstract}

Keywords disease control, European canker, biological fungicides.

\section{INTRODUCTION}

Neonectria ditissima conidia infect wounds in apple trees. The disease is managed by removal of sporulating European canker (canker) lesions and application of fungicides. Fungicides have been shown to provide wound protection, with a spring, summer, and autumn fungicide programme required to slow (but not stop) disease progression (Cooke 1999). Research by Cooke et al. (1993) showed that trees treated with dodine pre-blossom and dithianon postblossom tended to develop fewer cankers than those receiving a programme of spring-summer demethylation inhibitor (DMI) fungicides consisting of myclobutanil and penconazole. However, fewest cankers were observed using a carbendazim + captafol-based spring-summer programme. In contrast, a carbendazim autumntreatment was unsuccessful in disease control (Cooke et al. 1993). Carbendazim use in autumn for European canker control is not recommended in New Zealand (Walter et al. 2014), to minimise potential resistance development during the sexual reproduction of the pathogen (Swinburne 1975). Resistance of N. ditissima to carbendazim 
is possible (Weber \& Palm 2010), but fortunately it has not yet been reported in New Zealand to date (Walter et al. 2014).

Leaf scars are an important infection site (Swinburne 1975; Weber 2014). Chemical fungicides containing captan or copper applied during leaf fall have provided consistent canker control under New Zealand production conditions (Walter et al. 2015a). Additionally, Campbell et al. (2016) showed that in the 2015 New Zealand fruit harvest and leaf fall period, picking wound infections contributed approximately $75 \%$ to all new canker symptoms in an orchard. This trend was validated in 2016 (RE Campbell, pers. comm.). Amponsah et al. (2015) also showed that picking wounds are more susceptible than leaf scars to $N$. ditissima infection. Captan is not used during picking because of pre-harvest interval restrictions and copper or other chemical-based products are not used at this time due to fruit-quality issues (e.g. lenticel staining/russetting). Previous work has shown that Bacillus-containing biological products (BPs) have promise in reducing spore production by European canker lesions (Walter et al. 2017) and as wound protectants (Swinburne 1975). Therefore, the aim of this study was to further evaluate the use of New Zealand commercially available BPs for wound protection in apple trees, particularly of picking scars.

\section{MATERIALS AND METHODS}

Three field experiments were conducted; all in the Tasman sub-region of the Nelson province. Experiment 1 tested biological and agrichemical products for protection of picking wounds and leaf scars (Tables 1 and 2). The experiment was conducted during harvest and leaf fall in 2015 on a mature 'Scifresh'/Jazz' ${ }^{\mathrm{TM}}$ apple block, Little Sydney Valley, Riwaka. The aim of Experiment 2 was to further validate the use of biological products (Table 3) as wound protectants on 3-year-old 'Royal Gala' trees at The New Zealand Institute for Plant \& Food Research Ltd (PFR) Motueka research orchard during harvest in 2016. In Experiment 3, the effect of pathogen concentration on artificial wounds sprayed with selected BP was studied using 2-year-old 'Scilate'/ Envy $^{\mathrm{TM}}$ trees (PFR Motueka) treated in spring (September) 2016.

For each experiment, inoculum was prepared from field-collected cankers (Walter et al. 2015a) and made freshly in sterile distilled water $\left(4^{\circ} \mathrm{C}\right)$ on the day or the day prior to the inoculation. Spore concentrations were determined using a haemocytometer (Walter et al. 2015a). Cankers were always sourced from the same orchard block in the Riwaka area. Germination of spores was determined by pipetting $15 \mu \mathrm{L}$ spore suspension onto glass slides and incubating overnight at high humidity on the laboratory bench $\left(20^{\circ} \mathrm{C}\right)$.

\section{Experiment 1}

In this experiment, 11 products and one unsprayed Control were tested (Table 1). The site consisted of a 'Scifresh'/Jazz ${ }^{\mathrm{TM}}$ block, approximately 20 years old, on various rootstocks. The site was stand-alone, surrounded by paddocks with no other orchards within 100 $\mathrm{m}$ of the boundary. The orchard was leased, and fruit were not sold commercially because of the harvest treatments and picking wound inoculations. However, harvesting was carried out with all fruit being picked and dropped onto the ground, simulating three harvest picks. The orchard block consisted of 56 useable bays (post to post). There were six to nine trees/bay, depending on rootstock and missing trees. All trees in a bay (or plot) were sprayed, although the edge trees on each bay were not inoculated, but were used as buffers. Therefore, each plot in this trial had between four and seven trees for evaluation. Eight treatments were single products, the other three treatments were a combination of two products (Table 1) with either four or five replicate plots per treatment. The layout of the plots was derived from a Latinised resolvable block design constructed with CycDesign 5.1 (VSN International Ltd 2013).

On five different dates (Table 2), approximately 30 shoots per treatment plot were randomly selected (15 branches either side of the trees within the plot). Wounds (three/shoot) were created and the positions marked. All wounds 
Table 1 Assessment of control of Neonectria ditissima infections in picking wounds and leaf scars of 'Scifresh'/Jazz ${ }^{\mathrm{TM}}$ apple by biological products: Experiment 1 products and rates used.

\begin{tabular}{|c|c|c|c|c|c|}
\hline $\begin{array}{l}\text { Treatment } \\
\text { code }\end{array}$ & Product(s) & Supplier & Active ingredient(s) & $\begin{array}{l}\text { Product } \\
\text { rate }(s) \mathrm{kg} / \\
\text { ha }\end{array}$ & $\begin{array}{l}\text { Product } \\
\text { rate }(\mathrm{s}) \mathrm{g} / \\
\text { tree }\end{array}$ \\
\hline Control & Unsprayed & - & None & - & - \\
\hline BP 1 & Superzyme ${ }^{\mathrm{TM}}$ & $\begin{array}{l}\text { Roots, Shoots } \\
\text { \& Fruits }\end{array}$ & $\begin{array}{l}\text { Bacillus subtilis } \\
\text { Pseudomonas putida } \\
\text { Trichoderma koningii } \\
\text { T. harzianum }\end{array}$ & 2 & 1.6 \\
\hline BP 2 & Clarity & Grochem & B. subtilis MBI600 & 0.53 & 0.4 \\
\hline BP 6 & Fulzyme ${ }^{\circledR}$ Plus & $\begin{array}{l}\text { Roots, Shoots } \\
\text { \& Fruits }\end{array}$ & B. subtilis + amino acids & 2 & 1.6 \\
\hline BP 7 & $\mu$ Inoculant PP9 & Biostart & P. putida & 0.05 & 0.04 \\
\hline BP 9 & Vinevax $^{\mathrm{TM}}$ & $\begin{array}{l}\text { Agrimm } \\
\text { Technologies }\end{array}$ & T. harzianum & 1 & 0.8 \\
\hline $\begin{array}{l}\text { Captan } \\
\text { control }\end{array}$ & $\begin{array}{l}\text { FruitFed Captan } \\
\text { WG80 }\end{array}$ & FruitFed & Captan & 1.25 & 1.0 \\
\hline Oct & Eurogel & $\begin{array}{l}\text { Omnia } \\
\text { Nutriology }\end{array}$ & Octhilinone, boric acid & 4 & 3.2 \\
\hline $\begin{array}{l}\text { PAt } \\
\text { captan }\end{array}$ & $\begin{array}{l}\text { Phosgard + } \\
\text { FruitFed Captan } \\
\text { WG80 }\end{array}$ & Grochem & $\begin{array}{l}\text { Phosphorous acid }+ \\
\text { captan }\end{array}$ & $5+1.25$ & $4+1.0$ \\
\hline SA & Treet $^{\mathrm{TM}}$ & Grochem & $\begin{array}{l}\text { Hydroxy benzoic acid } \\
\text { (salicylic acid) }\end{array}$ & 3 & 2.4 \\
\hline $\mathrm{SA}+\mathrm{Cu}$ & $\begin{array}{l}\text { Treet }^{\mathrm{TM}}+ \\
\text { Nordox } 75 \mathrm{WG}\end{array}$ & Grochem & $\begin{array}{l}\text { Hydroxy benzoic acid + } \\
\text { Copper oxide }\end{array}$ & $3+1.3$ & $2.4+1.0$ \\
\hline SL & Slaked lime & Webster & Calcium hydroxide & 75 & 60 \\
\hline
\end{tabular}

${ }^{\mathrm{A}}$ Foliacin added as a co-substrate at a rate of $10 \mathrm{~mL} / \mathrm{litre}$. Supplied by Biostart.

were created by removing either the fruit, leaf or bud before the fungicide application (Table 2). The following day, spray treatments were applied and wounds were inoculated with the pathogen as described by Walter et al. (2015a). Products were applied using two STIHL $^{\circledR}$ air-assisted motorised knapsacks at a water rate of $1000 \mathrm{~L} / \mathrm{ha}$. The first two inoculations were on picking scars (coinciding with the first and third commercial picks) where fruit were removed. Inoculations 3 and 4 were on leaf scars (approximately 10\% and $60 \%$ natural leaf fall). For the last (fifth inoculation), bud scars (95\% leaf fall) were created. In total, 8,082 shoots were tagged, and thus 24,246 wounds were created.
Statistical analysis. The total number of picking scars per shoot that exhibited infection was calculated as the maximum across the assessments. For each inoculation date and each tree, the total inoculated scars, and the total showing infection were calculated. The number showing infection/total inoculated was analysed with a binomial-beta hierarchical generalised linear model (HGLM, Lee et al. 2006), with logit links for both fixed and random effects. This included: treatments, inoculation time and their interaction as fixed effects (fitted with a binomial distribution), and plots and trees within plots as random effects (fitted with a beta distribution). Overall assessments of fixed and random 
Table 2 Experiment 1 overview of treatment dates (2015) for wounding, spraying and inoculation with Neonectria ditissima in 'Scifresh'/Jazz ${ }^{\mathrm{TM}}$ apple: wound types used, inocula concentrations and germination rates in a $15-\mu \mathrm{L}$ water droplet at room temperature.

\begin{tabular}{|c|c|c|c|c|c|}
\hline & $\begin{array}{l}\text { Treatment } \\
\text { date } 1\end{array}$ & $\begin{array}{l}\text { Treatment } \\
\text { date } 2\end{array}$ & $\begin{array}{l}\text { Treatment } \\
\text { date } 3\end{array}$ & $\begin{array}{l}\text { Treatment } \\
\text { date } 4\end{array}$ & $\begin{array}{l}\text { Treatment } \\
\text { date } 5\end{array}$ \\
\hline Wound type & Picking scar & Picking scar & Leaf scar & Leaf scar & Bud scar \\
\hline Total scars/block & 4932 & 4938 & 4827 & 4776 & 4782 \\
\hline Wounding date & 30 Mar & $10 \mathrm{Apr}$ & $18 \mathrm{Apr}$ & 4 Jun & 15 Jun \\
\hline Spraying date & 31 Mar & $11 \mathrm{Apr}$ & $19 \mathrm{Apr}$ & 5 Jun & 15 Jun \\
\hline Inoculation date & $1 \mathrm{Apr}$ & $11 \mathrm{Apr}$ & $19 \mathrm{Apr}$ & 5 Jun & 15 Jun \\
\hline Tree status & First pick & Third pick & $10 \%$ Leaf fall & $60 \%$ Leaf fall & $95 \%$ Leaf fall \\
\hline $\begin{array}{l}\text { Spore concentration } \\
\text { (conidia/mL) }\end{array}$ & $1.2 \times 10^{5}$ & $1.0 \times 10^{5}$ & $1.0 \times 10^{5}$ & $8.0 \times 10^{4}$ & $1.0 \times 10^{5}$ \\
\hline Germination rate $(\%)$ & 65 & 28 & 50 & 39 & 38 \\
\hline
\end{tabular}

effects were made using $\chi^{2}$ tests of the change in deviance on dropping the term, as implemented in GenStat's HGFTEST and HGRTEST procedures (GenStat Committee 2015). Results are presented as predicted means and associated 95\% confidence limits. These were obtained on the link (log) scale, and back-transformed for presentation.

For overall means (main effects, treatment means over inoculation times for each of picking and leaf scars), the same random effects model but with the required main effects was re-fitted, but using the dispersion components (for plots, trees, and within trees) as estimated from fitting the model with the full fixed effects term (treatment by inoculation time). This gives a similar weighting to the data in the predictions for means whilst avoiding the marginality problems associated with predictions obtained after fitting the full model. All analyses were carried out with GenStat (GenStat Committee 2015).

\section{Experiment 2}

The trial area comprised five rows of 50 'Royal Gala' trees (on 'M9' rootstocks) per row, with four trees consisting of a treatment plot, and generally one buffer plant between plots. Five replicates of the ten treatments (Table 3) were laid out as a Latinised resolvable block design, generated with
CycDesign 5.1 (VSN International Ltd 2013). In this design, each row of trees contained a complete replicate of the treatments.

Rasp wounds were included in the test as these are more susceptible to infection than picking wounds (Amponsah et al. 2015) and to counter another potential 'low disease year' as had been found in 2015 during Experiment 1. Picking wounds (8/tree) and rasp-wounds (2/shoot with 2 shoots/tree) were created during late 'Royal Gala' harvest on 13 April 2016. Each wound was sprayed with one of the biological-product treatments with a hand-held misting bottle targeting the wound site by applying two puffs of approximately $0.5 \mathrm{~mL}$ to each wound area. The following day, approximately $24 \mathrm{~h}$ later, the wounds were inoculated with $N$. ditissima spore suspension (Walter et al.2015a). The spore concentration used was $5 \times 10^{4}$ conidia/mL. Inoculated wounds were monitored regularly, with first disease expression recorded on 12 July 2016 approximately 3 months after inoculation. At each assessment (12 July, 6 August, 12 and 23 September 2016), wounds showing symptoms were cut and removed. At the last assessment, the majority of wounds expressed symptoms, therefore all inoculated sites were cut from the plants. Shoots were cut if one or both rasp wounds showed symptoms, hence data have been analysed using percentage shoot cut, 
Table 3 Assessment of control of Neonectria ditissima infections in picking and rasp wounds of 'Royal Gala' apple by biological products: Experiments 2 and 3 biological products (BPs) used and product rates thereof.

\begin{tabular}{|c|c|c|c|c|c|c|}
\hline $\begin{array}{l}\text { BP } \\
\text { code }\end{array}$ & Product & Supplier & $\begin{array}{l}\text { Active ingredient(s) } \\
\text { (a.i.) }\end{array}$ & $\begin{array}{l}\text { a.i. } \\
\text { Concentration }\end{array}$ & $\begin{array}{l}\text { Exp. } 2 \\
\text { Product } \\
\text { rate used }\end{array}$ & $\begin{array}{l}\text { Exp. } 3 \\
\text { Product } \\
\text { rate used }\end{array}$ \\
\hline Control & Unsprayed & - & - & - & Unsprayed & Unsprayed \\
\hline BP1 & Superzyme $\mathrm{T}^{\mathrm{TM}}$ & $\begin{array}{l}\text { Roots, } \\
\text { Shoots \& } \\
\text { Fruits }\end{array}$ & $\begin{array}{l}\text { Bacillus subtilis } \\
\text { Pseudomonas putida } \\
\text { Trichoderma koningii } \\
\text { T. harzianum }\end{array}$ & $2 \times 10^{9} \mathrm{cfu} / \mathrm{g}$ & $1 \mathrm{~g} /$ litre & - \\
\hline BP 2 & Clarity & Grochem & B. subtilis MBI600 & $5.5 \times 10^{9} \mathrm{cfu} / \mathrm{g}$ & $2 \mathrm{~g} /$ litre & $2 \mathrm{~g} /$ litre \\
\hline BP 3 & $\begin{array}{l}\text { Serenade }^{\circledR} \\
\text { Optimum }\end{array}$ & $\begin{array}{l}\text { Bayer } \\
\text { CropScience }\end{array}$ & B. subtilis QST713 & $\begin{array}{l}1.3 \times 10^{10} \\
\mathrm{cfu} / \mathrm{g}\end{array}$ & $2 \mathrm{~g} /$ litre & $2 \mathrm{~g} /$ litre \\
\hline BP 4 & Bacstar $^{\mathrm{TM}}$ & $\begin{array}{l}\text { Etec Crop } \\
\text { Solutions } \\
\text { Ltd }\end{array}$ & $\begin{array}{l}\text { B. subtilis var. } \\
\text { amyloliquefaciens } \\
\text { D747 }\end{array}$ & $5 \times 10^{10} \mathrm{cfu} / \mathrm{g}$ & $2 \mathrm{~g} /$ litre & - \\
\hline BP 5 & Bacstar $^{\mathrm{TM}}$ & $\begin{array}{l}\text { Etec Crop } \\
\text { Solutions } \\
\text { Ltd }\end{array}$ & $\begin{array}{l}\text { B. subtilis var. } \\
\text { amyloliquefaciens } \\
\text { D747 }\end{array}$ & $5 \times 10^{10} \mathrm{cfu} / \mathrm{g}$ & $1 \mathrm{~g} /$ litre & - \\
\hline BP 6 & $\begin{array}{l}\text { Fulzyme }^{\circledR} \\
\text { Plus }\end{array}$ & $\begin{array}{l}\text { Roots, } \\
\text { Shoots \& } \\
\text { Fruits }\end{array}$ & $\begin{array}{l}\text { B. subtilis + amino } \\
\text { acids }\end{array}$ & $2 \times 10^{10} \mathrm{cfu} / \mathrm{g}$ & $2 \mathrm{~g} /$ litre & - \\
\hline BP 7 & $\begin{array}{l}\mu \text { Inoculant } \\
\text { PP9A }^{A}\end{array}$ & $\begin{array}{l}\text { BioStart } \\
\text { Ltd }\end{array}$ & P. putida Ps1 & $>10^{9} \mathrm{cfu} / \mathrm{mL}$ & $\begin{array}{l}0.25 \mathrm{~mL} / \\
\text { litre }\end{array}$ & - \\
\hline BP 8 & TripleX ${ }^{\mathrm{TM}}$ & $\begin{array}{l}\text { Biostart } \\
\text { Ltd }\end{array}$ & $\begin{array}{l}\text { B. amyloliquefaciens } \\
\text { Bs1b }\end{array}$ & $>10^{6} \mathrm{cfu} / \mathrm{mL}$ & $\begin{array}{l}10 \mathrm{~mL} / \\
\text { litre }\end{array}$ & - \\
\hline Captan & $\begin{array}{l}\text { Fruitfed } \\
\text { Captan WG80 }\end{array}$ & FruitFed & Captan & $800 \mathrm{~g} / \mathrm{kg}$ & $1.5 \mathrm{~g} /$ litre & $1.5 \mathrm{~g} /$ litre \\
\hline
\end{tabular}

${ }^{\text {A }}$ Foliacin added as a co-substrate at a rate of $10 \mathrm{~mL} /$ litre. Supplied by Biostrat Ltd.

percentage rasp wound infected and percentage spurs (picking wounds) infected.

Statistical analyses. The percentages of cut shoots, rasp wounds and spurs showing lesions were analysed with binomial generalised linear model (GLM) (McCullagh \& Nelder 1989) with a logit link. This included an overall test for treatment differences within an analysis of deviance, which was a $\chi^{2}$ test where the data were not over dispersed ( $\%$ cut shoots), or F-test where the data were over dispersed (wounds and spurs showing lesions). Comparisons of individual treatments with the positive control (captan control) or Control (unsprayed) were made using contrasts within this analysis. In the results, percentages are presented along with 95\% confidence limits. These were obtained on the link (logit) scale, and back-transformed for presentation. The analyses were carried out with GenStat (Payne et al. 2015).

\section{Experiment 3}

In the absence of picking wounds, a small study on the interaction of two selected biological products (BP 2 and $\mathrm{BP} 3$ ) and $N$. ditissima conidial concentration was conducted on rasp wounds in September 2016.

This experiment was carried out on 2-yearold 'Scilate'/Envy ${ }^{\mathrm{TM}}$ trees on 'M9' rootstocks. The trial area comprised one row with 98 trees. There were five replicates, with treatments arranged 
randomly within a replicate block along the row. Treatments (Control, captan, BP 2 [Clarity], BP 3 [Serenade]; Table 3) were applied to the west side of the trees only. A treatment plot consisted of two treated plants and one buffer plant. On each treated plant three shoots were selected, one for each conidial concentration $\left(4 \times 10^{2}, 4 \times 10^{3}, 4 \times 10^{4}\right.$ conidia/mL). Each shoot had three rasp wounds (approximately $10 \mathrm{~cm}$ apart from each other) which were sprayed on 28 September 2016 with the product (as described in Experiment 2) in the late afternoon after wounding. The next day, again in the late afternoon, wounds were inoculated with a $10-\mu \mathrm{L}$ droplet of spore suspension at the lower edge of the wound, resulting in approximately 4 , 40 or 400 spores/wound.

Inoculated wounds were monitored, with first disease expression recorded on 16 December 2016. Again, inoculated wounds showing symptoms were cut and removed. Three more assessments were made, on 16 January, 23 February, and 4 April 2017. With low disease expression, data are presented in descriptive form only.

\section{RESULTS AND DISCUSSION \\ Experiment 1}

Overall, disease expression was low in this experiment, but for this season was on par with other disease data in the region (Dryden et al. 2016). Picking scars, on average, were almost three times $(\mathrm{P}<0.001)$ more likely to be infected $(5.7 \%$ overall) than were leaf scars $(2.2 \%)$, with bud scar $(5 \%)$ inoculations also yielding more infections $(\mathrm{P}<0.001)$ than on leaf scars. This supports previous research where higher susceptibility of picking wounds than leaf scar wounds was also shown by Amponsah et al. (2015), and higher susceptibility of bud scars than leaf scars was shown by Scheper et al. (unpubl. data).

For all wounds, highest infections were generally observed in the slaked lime and the Control treatments, with lowest infections recorded in the two captan treatments. Treatment effects were similar for the two picking wound inoculation treatments. However, this was not the case for the two leaf scar and one bud scar inoculation treatments (treatment $\mathrm{x}$ inoculation timings $\mathrm{P}<0.001)$. Thus, the treatments that were most and least efficacious were not the same at the three leaf fall inoculation times (Figure 1). After pooling the data for the two picking wound inoculations only, the two captan treatments produced significantly different $(\mathrm{P}<0.05)$ results from the Control treatment, in which the most lesions developed. Pooling the data for the three leaf fall applications/inoculation timings, all treatments were similar to the Control treatment $(\mathrm{P}>0.05)$, however the two captan plus the salicylic acid + copper oxide treatments were lower $(\mathrm{P}<0.05)$ than the slaked lime treatment, which developed the most symptoms. This trend of the captan and copper oxide treated consistently showing lower leaf scar infections agrees with earlier work (Walter et al. 2015a).

As mentioned above, symptom development was low for artificial infections during the 2015 harvest and leaf fall period. The reasons are not fully understood, but were typical for all experiments in the 2015 postharvest period. Further research on climatic factors driving infection and symptom development are in progress. Nonetheless, all products (albeit not significant at the $\mathrm{P}>0.05$ level) reduced the percentage of infections on picking scars (Figure 1). Therefore, the use of biological fungicides was further investigated during the harvest period (Experiment 2).

\section{Experiment 2}

Disease incidence for the Controls was markedly higher in Experiment 2 compared with Experiment 1 despite approximately ten-fold fewer spores being used for inoculations in Experiment 2. For rasp wounds, both the percentage of shoots cut and inoculated rasp wounds that developed lesions (Figure 2) varied substantially with treatment $(\mathrm{P}<0.001$ overall). Percentages were much lower with captan $(66 \%$ and $47 \%$, respectively) than with any other treatment, significantly so in all cases $(\mathrm{P}=0.018$ or smaller). In comparison with the Controls (98\%), the percentage of cut shoots with lesions was fairly similar in all treatments except captan $(\mathrm{P}>0.5$; all $>95 \%)$. The pattern was similar for rasp wounds developing lesions (all 
$>86 \%$, except for captan; with $94 \%$ for Control; $\mathrm{P}>0.2$ for the comparison with Control).

Captan was also effective in reducing infection on picking wounds $(\mathrm{P}<0.001)$, with approximately $28 \%$ of inoculated picking wounds developing lesions, compared with the unsprayed Control at $80 \%$ (Figure 3 ). Of the BP treatments,
BP 7 ( $P$. putida+foliacin) resulted in the fewest lesions (60\%), significantly fewer than in the unsprayed Control $(P=0.023)$. Percentages were similar in all the BP treatments, the highest being $74 \%$ with BP 5 (B. subtilis var. amyloliquefaciens D747, low rate), although lower lesion formation on picking wounds occurred in all BP treatments

(A)

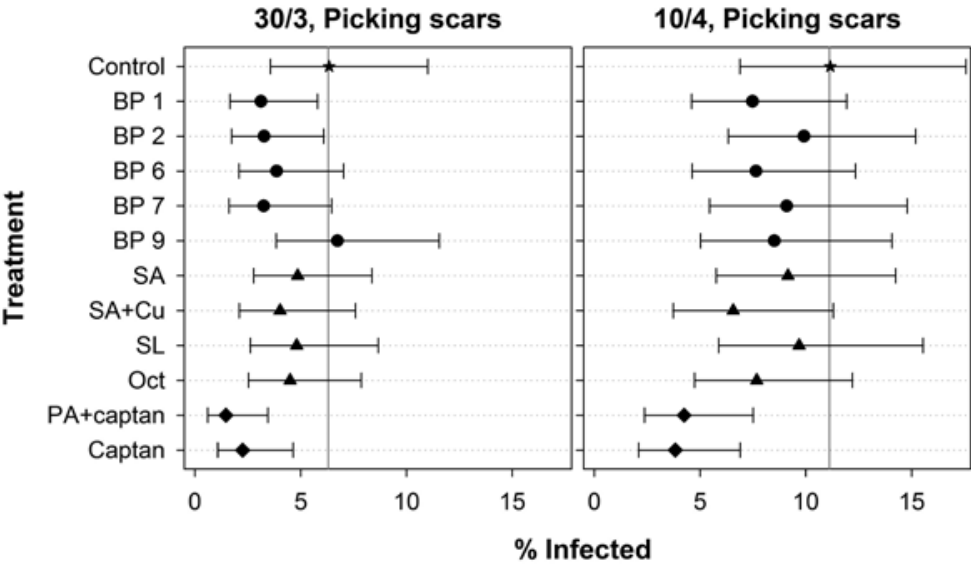

(B)
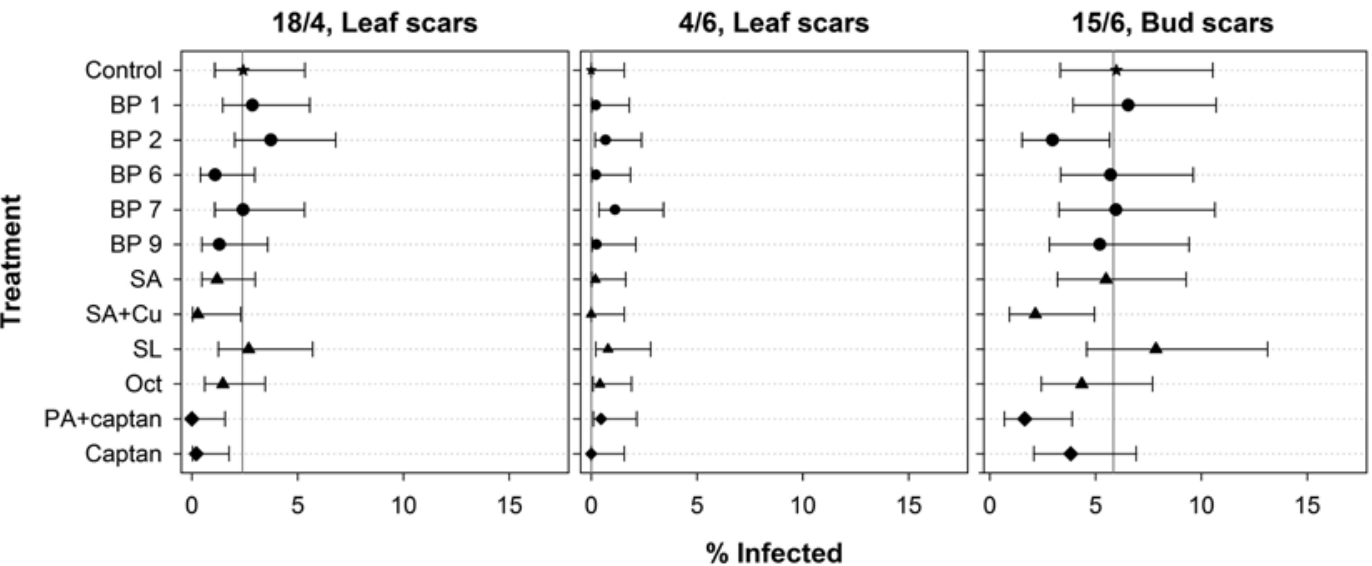

Figure 1 Mean percentage of Neonectria ditisima-infected scars in 'Scifresh'/Jazz ${ }^{\mathrm{TM}}$ apple, for each of the 12 treatments, for each inoculation time (Experiment 1). Results are shown separately for each inoculation time (A) during harvest and (B) during leaf fall, with the first inculation on the 30 March 2015. Error bars show 95\% confidence limits for the means, and the vertical grey line is the mean for the unsprayed Control, within each panel. Product codes are further described in Table 1: Control = Unsprayed; $\mathrm{BP} 1=$ B. subtilis + P. putida + Trichoderma koningii + T. harzianum; $\mathrm{BP} 2=$ B. subtilis MBI600; BP 6=Bacillus subtilis + amino acids; BP $7=$ Pseudomonas putida + foliacin; $\mathrm{BP} 9=$ Trichoderma harzianum; SA = Salicylic acid; SA + Cu = Salicylic acid + copper oxide; $\mathrm{SL}=$ Slaked lime; Oct = Octhilinone + boric acid; PA + captan = Phosphorous acid + captan; Captan = Captan control. 
than in the unsprayed Control (statistically significant only for BP 5; Figure 3).

In Experiment 2, there was limited to no benefit in preventing disease development

(A)

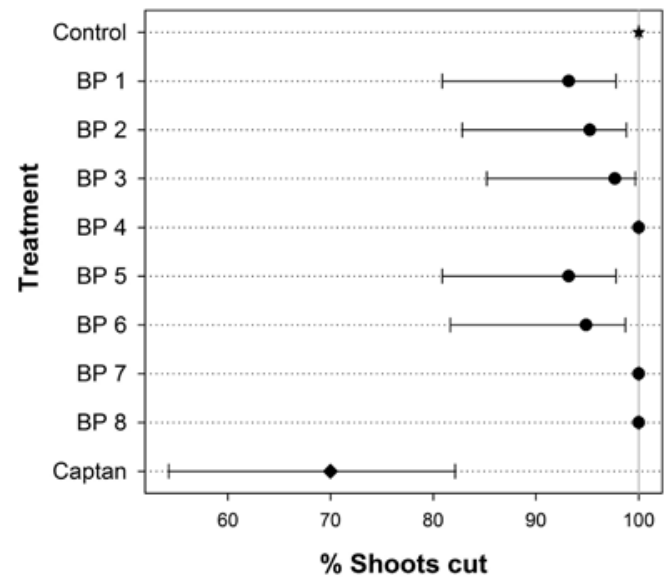

when applying biological products to picking or rasp wounds after challenge-inoculation in April (autumn) with $N$. ditissima at a spore concentration of $5 \times 10^{4}$ conidia $/ \mathrm{mL}$.

(B)

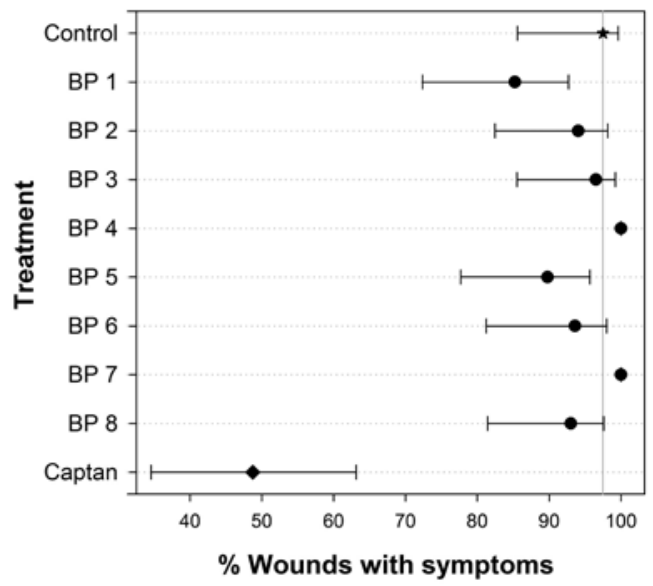

Figure 2 (A) Percentage of 'Royal Gala' apple shoots removed which developed lesions on Neonectria ditissima-inoculated rasp wounds (2/shoot) and (B) percentage of all rasp wounds developing lesions (Experiment 2). A shoot was removed if one or both rasp wounds showed symptoms. Error bars are 95\% confidence limits. (Note that the lower limit for treatments with means of $100 \%$ cannot be easily calculated, so these are not shown). The vertical grey line denotes the percentage for the Control. Product codes are further described in Table 3: Control $=$ Unsprayed; BP $1=$ B. subtilis + P. putida + Trichoderma koningii + T. harzianum; BP $2=B$. subtilis MBI600; BP $3=B$. subtilis $\mathrm{QST} 713$; $\mathrm{BP} 4=$ B. subtilis var. amyloliquefaciens D747 (high rate); BP $5=$ B. subtilis var. amyloliquefaciens D747 (low rate); BP $6=$ B. subtilis + amino acids; BP $7=$ Pseudomonas putida + foliacin; BP $8=$ Bacillus amyloliquefaciens Bs1b; Captan = Captan control.

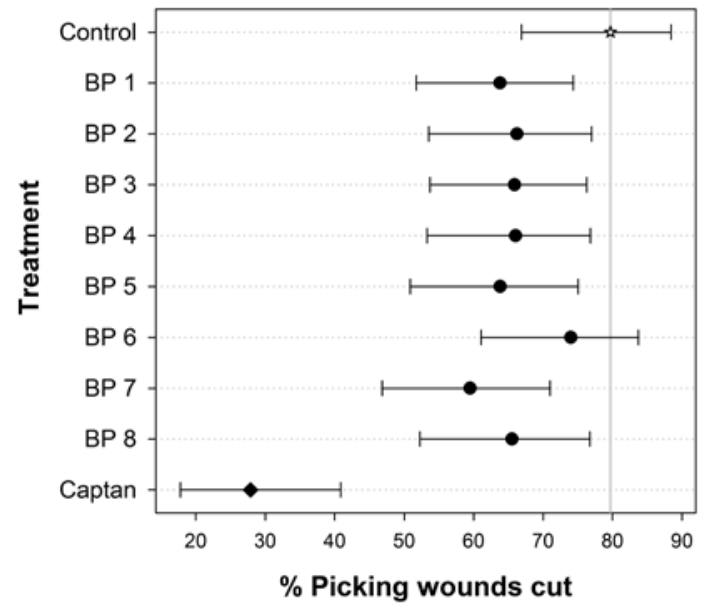

Figure 3 Percentage of 'Royal Gala' apple spurs removed after developing symptoms on the Neonectria ditissima-inoculated picking wounds during harvest 2016, with treatments shown in order of the means (Experiment 2). Error bars are $95 \%$ confidence limits. The vertical grey line denotes the percentage for the unsprayed Control. Product codes are further described in Table 3: Control $=$ Unsprayed; BP $1=$ B. subtilis + P. putida + Trichoderma koningii + T. harzianum; BP $2=$ B. subtilis MBI600; BP $3=$ B. subtilis QST713; BP $4=$ B. subtilis var. amyloliquefaciens D747 (high rate); $\mathrm{BP} 5=$ B. subtilis var. amyloliquefaciens $\mathrm{D} 747$ (low rate); BP $6=$ B. subtilis + amino acids; BP 7 $=$ Pseudomonas putida + foliacin; BP $8=$ Bacillus amyloliquefaciens Bs1b; Captan = Captan control. 


\section{Experiment 3}

Disease expression was very low throughout this experiment. Only one inoculated wound (4 conidia/wound) in the unsprayed Control developed visible symptoms during the six months of observation (September 2016 to April 2017), data not shown. For the inoculations using 40 conidia/ wound, two lesions developed in each product treatment. At the higher spore concentration of 400 conidia/wound, wounds in the Control treatment developed the most symptoms (six lesions), followed by those in the two BP treatments (three lesions each) and captan (one lesion). This study confirms earlier research (Walter et al. 2016) that spore concentration affects the rate of lesion development. The low disease expression may have been due to the spring inoculation, only 22 from 540 inoculated wounds (4\%) developed visible symptoms, compared with $>60 \%$ of pruning cuts (Amponsah et al. 2015) and 33\% of rasp wounds (Amponsah et al. 2017) on 'Scilate' trees. Further work is currently underway to determine the rate of infection versus rate of disease expression based on product treatment and spore concentration. Specifically, a subset of inoculated wounds that did not show disease symptoms are being processed for pathogen re-isolation from the wound edge onto apple sap amended water agar (ASAWA) as described by Walter et al. (2016)

\section{GENRAL DISCUSSION AND CONCLUSION}

With the brush-droplet inoculation (Walter et al. 2015 a), approximately $20-30 \mu \mathrm{L}$ of spore suspension were applied to a wound, depositing approximately 1000 to 1500 spores/wound. Although 10 conidia were sufficient to cause infection and symptoms in field studies, the larger the wound and the higher the spore concentration, the more lesions developed and the shorter the latent period from infection to symptom expression (Walter et al. 2016). Experiments 1 and 2 demonstrated that biological products will not provide adequate wound protection when challenge-inoculated with a high pathogen load. However, under low disease pressure biological products might be more competitive (Experiment 3).

In the three experiments described here, biological products provided little to no protection of wounds to $N$. ditissima infections at high disease pressure (>1000 spores/wound). Bacillus subtilis isolates were antagonistic to $N$. ditissima in vitro, and control of leaf scar infections was achieved (Swinburne et al. 1975; Swinburne 1973). However, in a two-year field study Swinburne \& Brown (1976) found that the bacterium alone was not effective without additional applications of dithianon. Dithianon alone was less effective than in combination with B. subtilis.

The range of inoculum concentrations $\left(4 \times 10^{2}\right.$ $-1.2 \times 10^{5}$ conidia/mL) used in the experiments conducted here are realistic since between 100 (detection threshold) and >40,000 N. ditissima spores $/ \mathrm{mL}$ have been collected in rain traps underneath European canker lesions in oneyear-old 'Royal Gala' and 'Scilate' shoots in New Zealand (unpublished data). Most spores disperse within the proximity $(0.42 \mathrm{~m})$ of the lesion but about half of all spores finally settle $>0.42 \mathrm{~m}$ from the inoculum source, although only $4 \%$ at $>2 \mathrm{~m}$ (Walter et al. 2015b), which is known as the "hot spot" nature of disease progression (Campbell et al. 2016). Therefore, wounds near a sporulating lesion will be exposed to higher inoculum pressure than wounds at a distance.

Biological products did not provide adequate wound protection when challenge-inoculated with $N$. ditissima at high concentration $(>1000$ spores/wound). The biological products tested, when applied alone, are not recommended for wound protection during harvest and leaf fall because of the lack of protection they provide under high spore loading.

\section{ACKNOWLEDGEMENTS}

This work was funded by Pipfruit New Zealand Inc. with co-funding from product suppliers. The advice received on product use has been welcomed.

\section{REFERENCES}

Amponsah NT, Walter M, Beresford RM, Scheper RWA 2015. Seasonal wound presence and susceptibility to Neonectria ditissima infection in New Zealand apple trees. New Zealand Plant Protection 68: 250-256. 
Amponsah NT, Walter M, Scheper RWA, Beresford RM 2017. Neonectria ditissima spore release and availability in New Zealand apple orchards. New Zealand Plant Protection 70: 78-86.

Campbell RE, Roy S, Curnow T, Walter M 2016. Monitoring methods and spatial patterns of European canker disease in commercial orchards. New Zealand Plant Protection 69: 213-220.

Cooke LR 1999. The influence of fungicide sprays on infection of apple cv. Bramley's seedling by Nectria galligena. European Journal of Plant Pathology 105: 783-790.

Cooke LR, Watters BS, Brown AE 1993. The effect of fungicide sprays on the incidence of apple canker (Nectria galligena) in Bramley's Seedling. Plant Pathology 42: 432-442

Dryden GH, Nelson MA, Smith JT, Walter M 2016. Postharvest foliar nitrogen applications increase Neonectria ditissima leaf scar infections in apple trees. New Zealand Plant Protection 69: 230-237.

GenStat Committee. 2015. The Guide to the GenStat ${ }^{\circledR}$ Command Language (Release 18). VSN International, Hemel Hempstead, Hertfordshire, UK.

Lee Y, Nelder JA, Pawitan Y. 2006. Generalized Linear Models with Random Effects: Unified Analysis via H-likelihood. Chapman \& Hall/ CRC Press, London. 416.p.

McCullagh P, Nelder JA. 1989. Generalized Linear Models. Chapman \& Hall, London, 511+xix p. Payne R, Murray D, Harding S. 2015. The Guide to the Genstat ${ }^{\circledR}$ Command Language (Release 18). VSN International, Hemel Hempsted, Hertfordshire, UK.

Swinburne TR 1973. Microflora of apple-leaf scars in relation to infection by Nectria galligena. Transactions of the British Mycological Society 60: 389-403.

Swinburne TR 1975. European canker of apple. Review of Plant Pathology 54: 787-799.

Swinburne TR, Cartwright J, Flack NJ, Brown AE 1975. The control of apple canker (Nectria galligena) in young orchard with established infections. Annals of Applied Biology 81: 61-73 Swinburne TR, Brown AE 1976. A comparison of the use of Bacillus subtilis with conventional fungicides for the control of apple canker (Nectria galligena). Annals of Applied Biology 82: 365-368.

VSN International Ltd. 2013. CycDesigN 5.1 A package for the computer generation of experimental designs. Version 4.0, VSN International Ltd, Hertfordshire, England.

Walter M, Stevenson OD, Amponsah NT, Scheper RWA, McLachlan ARG 2014. Sensitivity of Neonectria ditissima to carbendazim fungicide in New Zealand. New Zealand Plant Protection 67: 133-138.

Walter M, Stevenson OD, Amponsah NT, Scheper RWA, Rainham D, Hornblow C, Kerer U, Dryden G, Latter I, Butler RC 2015a. Control of Neonectria ditissima with copper based products in New Zealand. New Zealand Plant Protection 68: 241-249.

Walter M, Amponsah NT, Wallis R, Lamberts R, Curnow T, Stevenson OD, Hall AJ 2015b. Rain splash of fungal spores in tree canopies. Australasian Plant Pathology Society Conference Handbook, Fremantle, September 2015, p. 82. (Abstract)

Walter M, Roy S, Fisher BM, Mackle L, Amponsah NT, Curnow T, Campbell RE, Braun P, Reinecke A, Scheper RWA 2016. How many conidia are required for wound infection of apple plants by Neonectria ditissima? New Zealand Plant Protection 69: 238-245.

Walter M, Campbell RE, Amponsah AT, Scheper RWA, Butler C 2017. Evaluation of biological and agrichemical products for control of Neonectria ditissima conidia production. New Zealand Plant Protection 70: 87-96.

Weber RWS 2014. Biology and control of the apple canker fungus Neonectria ditissima (syn. N. galligena) from a Northwestern European perspective. Erwerbs-Obstbau: DOI 10.1007/ s10341-014-0210-x.

Weber RWS, Palm G 2010. Resistance of storage rot fungi Neofabraea perennans, N. alba, Glomerella acutata and Neonectria galligena against thiophanate-methyl in Northern German apple production. Journal of Plant Diseases and Protection 117 (4): 185-191. 